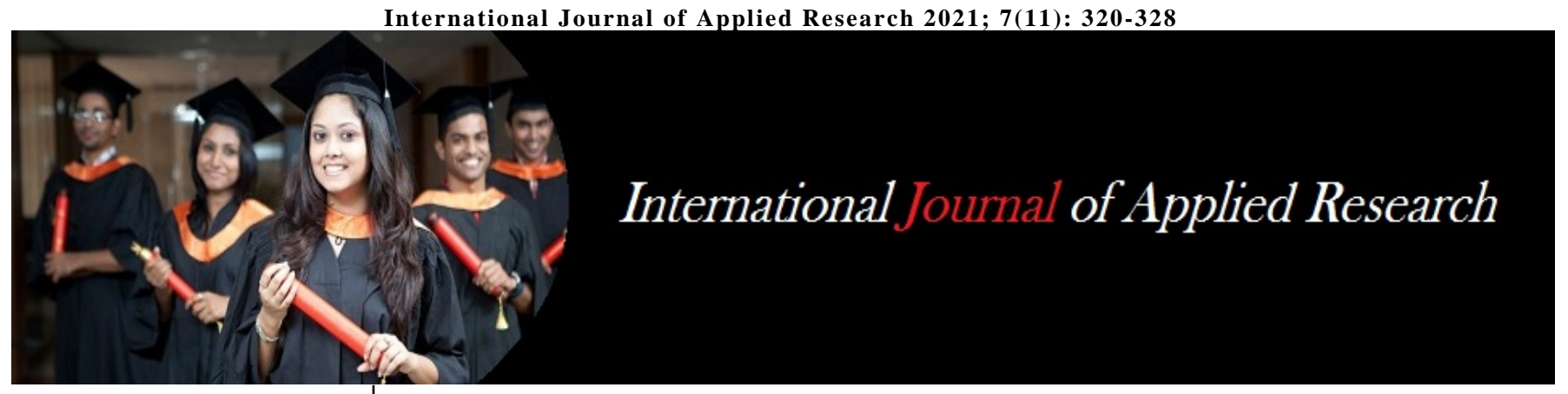

ISSN Print: 2394-7500 ISSN Online: 2394-5869 Impact Factor: 8.4 IJAR 2021; 7(11): 320-328 www.allresearchjournal.com Received: 11-09-2021 Accepted: 22-10-2021

Kpangui Kouassi Bruno University Jean Lorougnon Guédé, Training and Research Unit in Environment, BP 150

Daloa, Côte d'Ivoire

Koffi N'Guessan Achille University Jean Lorougnon Guédé, Training and Research Unit in Agroforestry, BP 150 Daloa, Côte d'Ivoire

Sangne Yao Charles University Jean Lorougnon Guédé, Training and Research Unit in Environment, BP 150 Daloa, Côte d'Ivoire

Kouakou Kouassi Apollinaire University Jean Lorougnon Guédé, Training and Research Unit in Environment, BP 150 Daloa, Côte d'Ivoire

Kouassi Jean-Luc

University Jean Lorougnon Guédé, Training and Research Unit in Environment, BP 150 Daloa, Côte d'Ivoire

Kouame Djaha

University Jean Lorougnon Guédé, Training and Research Unit in Environment, BP 150 Daloa, Côte d'Ivoire

N'guessan Kouakou Edouard Université Félix HouphouëtBoigny, Training and Research Unit in Biosciences, 22 BP 582 Abidjan 22, Côte d'Ivoire
Corresponding Author: Kpangui Kouassi Bruno University Jean Lorougnon Guédé, Training and Research Unit in Environment, BP 150 Daloa, Côte d'Ivoire

\section{Vegetation restoration after abandonment of human activities in soubre hydroelectric dam biodiversity Refugee zone (South-West Cote D'Ivoire)}

\author{
Kpangui Kouassi Bruno, Koffi N’Guessan Achille, Sangne Yao Charles, \\ Kouakou Kouassi Apollinaire, Kouassi Jean-Luc, Kouame Djaha and \\ N'guessan Kouakou Edouard
}

DOI: https://doi.org/10.22271/allresearch.2021.v7.i11e.9161

\section{Abstract}

The impacts of human activities have serious consequences for vegetation cover and the survival of plant species. This is the case of the Soubré Biodiversity Refuge Area, located in the southwest of Côte d'Ivoire. The general objective of this study is to assess the floristic diversity and the level of plant species recovery of the Soubré dam biodiversity refuge area since the dam was impounded. The methodology consisted of the installation of 29 plots of $20 \times 20 \mathrm{~m} \mathrm{(400} \mathrm{\textrm {m } ^ { 2 } )}$ and a systematic inventory of the flora within them. At the end of these inventories, it emerged that the flora of the refuge zone is rich in 143 species divided into 118 genera and 53 families. The area is dominated by small diameter stems. The high pioneer index in the former rubber tree cultivation reflects the very low reconstitution in this habitat.

Keywords: Soubré refuge zone, recovery, floristic diversity, pioneer index

\section{Introduction}

The global situation with regard to biological diversity remains worrying. Indeed, despite the efforts of the international community, biodiversity continues to be degraded by anthropogenic activities, including abusive logging, agricultural expansion, industrialisation and changes in the hydrological regime of rivers (Hassane, 2013) ${ }^{[13]}$, as well as by natural factors, including climate change. This degradation of biodiversity thus constitutes a threat to humanity (Sinsin \& Kampmann, 2010) ${ }^{[30]}$. In Africa, forest cover degradation has reached alarming proportions. Africa's forest cover has fallen from 749 million hectares in 1990 to 674 million hectares in 2010 (Forest resources assessment, 2010) ${ }^{[11]}$. In Côte d'Ivoire, forest cover, which in the 1900s was 16 million hectares, fell to 1.385 million hectares in 2000 (Koné et al., 2014) ${ }^{[21]}$. This forest degradation is most noticeable in the southwest of Côte d'Ivoire. The main reason for this is the expansion of agriculture. Indeed, agriculture has been and still is an important lever in the economic and human development of the country. After independence, the country structured its growth around agriculture. To achieve this objective, huge cash crop plantations (coffee, cocoa, oil palm, rubber, etc.) were created (Kassoum, 2018) ${ }^{[18]}$. However, while Côte d'Ivoire has enjoyed strong economic growth (8.5\% growth in 2016) largely based on its agricultural sector, this has been at the expense of its forest cover. Secondly, development projects such as the construction of roads, hospitals, schools, hydroelectric dams and the exploitation of mining resources are all factors that have led to the advanced degradation of vegetation in Côte d'Ivoire. The impacts of human activities on vegetation cover and the survival of plant species in particular have been highlighted by several authors (Adou et al., 2011; Missa et al., 2018) ${ }^{[2,24]}$. Faced with the continuous degradation of its biodiversity, the Ivorian government, through the forestry code, has adopted compensation methods in order to strengthen its protected areas (Koné et al., 2014) ${ }^{[21]}$. Firstly, these methods consist of setting up protected areas (national parks and reserves) and classified forests in order to reduce the effects of agriculture on biodiversity and secondly to set up an Environmental and Social Management Plan (ESMP) by creating biodiversity refuges for the ecological compensation of infrastructure development projects. 
As part of the ESMP, a biodiversity refuge area was created in Soubré during the construction of the hydroelectric dam in 2017 to compensate for the loss of ecological habitats. Today, the demographic boom and the lack of arable land have led to an intensification of forest clearing in and around the refuge area, which compromises, in the medium term, the preservation of biodiversity and sustainable development (Abrou, 2019) ${ }^{[1]}$. Knowledge of the diversity of flora is needed to contribute to the process of sustaining the flora. Anthropogenic activities threaten the refuge area, leading to the regression of areas or degradation of the physiognomy of the original vegetation. There is therefore a dynamic in place that is poorly understood and its effects need to be determined for better conservation. It should be noted that to date, few studies have been carried out on the impacts of human activities on the plant biodiversity of the Soubré refuge zone. Moreover, the management of such a site necessarily requires knowledge of its total and structural diversity both inside and outside (Sangne et al., 2015) ${ }^{[27]}$. The inadequacy or lack of scientific studies on the structure of the flora of the refuge area has raised the following questions: (1) what is the current state of recovery of the different habitats encountered in the Soubré refuge area since the hydroelectric dam was impounded? (2) What is the plant diversity of the refuge area? While attempting to answer the various questions mentioned above, the general objective of this study is to assess the floristic diversity and the level of reconstitution of plant species in the Soubré dam biodiversity refuge zone since the hydroelectric dam was impounded. Specifically, the aim is to (1) determine the species richness of the refuge area, (2) determine the vegetation structure of the area and (3) assess the level of regeneration of the different habitats.

\section{Material and Methods \\ 2.1 Study site}

This study took place in the Soubré Biodiversity Refuge Area (BRA), which is located in southwestern Côte d'Ivoire between $5^{\circ} 47^{\prime}$ north and $6^{\circ} 38^{\prime}$ west of the town of Soubré, the capital of the Nawa region. It was created in 2017 to compensate for the loss of ecological habitats and constitutes an ecological continuum of 200 hectares (ha) spread over the Sassandra River. The refuge area is bounded to the north by the Departments of Buyo and Issia, to the south by the Departments of San-Pedro and Sassandra, to the east by those of Gagnoa and Gueyo and to the west by the Department of Taï (Jeune Volontaire pour l'Environnement, 2017) ${ }^{[15]}$.

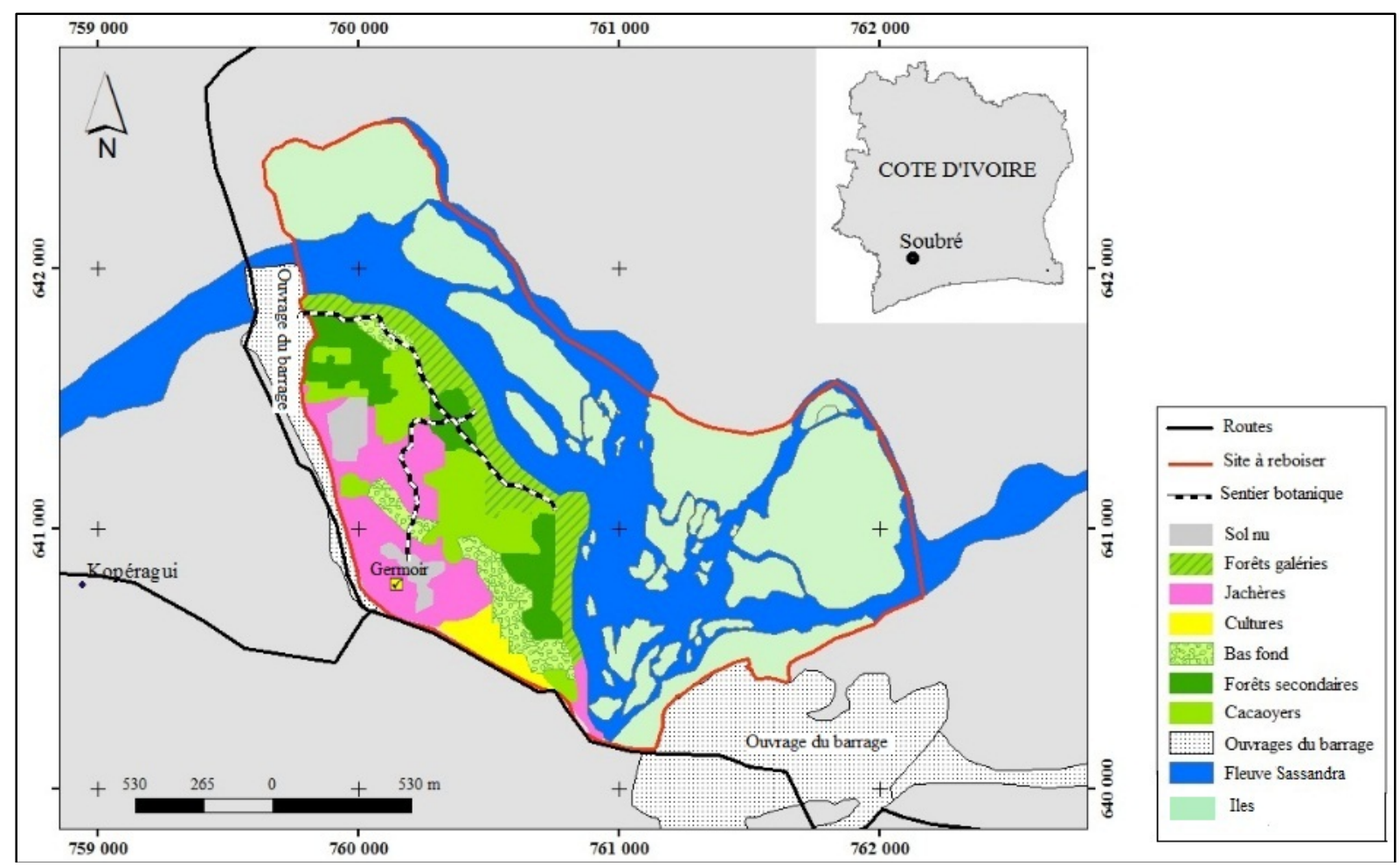

Fig 1: Location of the Soubré biodiversity refuge area

\subsection{Data collection}

Our data collection took place from June to July 2021. Several botanical inventory methods exist depending on the objectives of each study. Plot surveys and roving surveys were carried out. For the botanical inventories in the different habitats, plots of $20 \mathrm{~m} \mathrm{x} 20 \mathrm{~m}$, i.e. $400 \mathrm{~m}^{2}$, were used. Within these plots, all plant species encountered were identified and noted on the survey sheet bearing the number of the plot. The geographical coordinates of the plot were recorded with a GPS. In total, 29 plots were set up. These were 2 secondary forest plots, 9 former cocoa plots, 6 former annual crop plots, 3 former mixed crop plots, 5 former rubber plots and 4 bare soil plots. The circumference of woody individuals at $1.30 \mathrm{~m}$ from the ground was measured. This will allow the observation of the different vegetation stages of the site.

\subsection{Data analysis}

\subsubsection{Determination of the Floral composition}

Floristic richness is defined as the number of species recorded on a given territory (Aké-Assi, 1984) ${ }^{[4]}$. It is measured by counting all the species recorded in each biotope without taking into account their abundance. The same was done for the families and genera of these species. The species and their families were identified using the 
identification key proposed by Hawthorne (1996) ${ }^{[14]}$. The compilation of all these lists provided the number of species in each habitat (secondary forest, former crops and bare soil).

\subsubsection{Quantitative diversity of the Soubré refuge area 2.3.2.1. Species diversity}

Species diversity is a measure of the species composition of a stand that takes into account the number of species and their relative abundance. There are several indices for assessing this diversity. If we denote by $\mathrm{N}$, the number of species considered; $\mathrm{Ni}$, the number of individuals of a species $\mathrm{i}$ and $\mathrm{Pi}$, the relative abundance of species $\mathrm{i}$, then the Shannon index can be summarized by the following mathematical expression:

$$
H^{\prime}=-\sum P i * \ln P \boldsymbol{i}
$$

In this formula, $\mathrm{H}$ ' represents the Shannon diversity index, $\mathrm{Pi}=\mathrm{Ni} / \Sigma \mathrm{N}$ where $\mathrm{Pi}$ is the relative frequency of individuals of species $\mathrm{i}, \mathrm{Ni}$ is the number of individuals of species $\mathrm{i}$ and $\mathrm{N}$ is the total number of individuals of all species.

\subsubsection{Distribution of species in the refuge area}

For a stand, equitability provides information on the distribution of individuals among the different species. Thus, the calculation of the specific diversity index must always be accompanied by that of equitability, because two stands with different physiognomy can have the same diversity. The equitability $\mathrm{E}$ is obtained by relating the observed diversity to the maximum theoretical diversity.

Equitability varies from 0 to 1 . It tends towards 0 when almost all the numbers are concentrated on one species and towards 1 when all the species have the same abundance. If this index tends towards 1 , the environment in question is said to be balanced. The equitability index is calculated according to the following mathematical formula:

$$
E=\frac{H^{\prime}}{\ln S}
$$

\subsubsection{Species abundance in the refuge area}

Simpson's index (1949) [29] also measures the species composition of a stand by taking into account the species richness. The Simpson index is an index of dominance. It confirms the results of the Shannon index. It takes into account the measured frequency of species. Its formula is:

$$
D S=1-\sum_{i=1}^{S} P i^{2}
$$

It can be interpreted as the probability that two randomly selected individuals are of different species. When the Simpson index tends towards 0 , all species have the same abundance and when it tends towards 1 , only one species is present. In other words, the higher the DS, the higher the diversity.

\subsubsection{Similarity of habitats in the biodiversity refuge} area

Sorensen's (1948) ${ }^{[31]}$ coefficient of similarity was used to compare the environments inventoried, based on their floristic lists. The formula used is as follow:

$$
C s=\frac{2 C}{A+B} * 100
$$

Cs: Sorensen's coefficient of similarity;

$\mathrm{C}$ : the number of species common to both surveys a and b;

A: the total number of species present in survey a;

$B$ : the total number of species present in survey $b$;

$\mathrm{A}+\mathrm{B}$ : the total sum of species present in both surveys.

\subsubsection{Distribution of individuals by diameter class}

This is a measure of the demographic structure of the woody individuals. The distribution of stems by area was estimated by measuring the circumferences of trees and shrubs greater than or equal to 10 centimetres $(\mathrm{cm})$ using a tape measure. Individuals with a circumference of less than $10 \mathrm{~cm}$ were also counted. These woody individuals are grouped into four (4) diameter classes: $[0 ; 10[;[10 ; 20[,[30 ; 40]$ and $[50 ; \geq[$.

\subsubsection{Recovery of vegetation}

2.3.3.1. Mode of dissemination

The spatial distribution of plants is largely dependent on their ability to spread over a greater or lesser distance (Bouzillé, 2007) ${ }^{[7]}$. The "diaspore" is the structure of the plant that is involved in its dispersal (Hakizimana, 2012) ${ }^{[12]}$. According to Aké Assi, zoochory is the dissemination of diaspores by animals. This mode of dissemination can be external (Epizoochorie) or internal (Endozochorie). Barochory is the dissemination of diaspores without apparent adaptation, during which the diaspores break off and fall by gravity. Finally, Anemochory is the dissemination of diaspores by the wind. For the determination of diaspore types, we compared our list of species with those of Martin (2008) ${ }^{[23]}$ and Koffi (2016) ${ }^{[20]}$.

\subsubsection{Pioneer index}

The pioneer index represents the proportion of pioneer species and non-pioneer sun-loving species and makes it possible to determine the state of disturbance or recovery of a site (Sheil and Van Heist, 2000) ${ }^{[28]}$. This index has already been used in Côte d'Ivoire by Adou (2005) ${ }^{[3]}$, Vroh et al. (2011) ${ }^{[34]}$ and Koffi (2016) ${ }^{[20]}$. This index (PI) has five classes of values (Table I) and does not take into account species in hydromorphic environments. It has the formula:

$$
\mathbf{I P}=100(2 \mathrm{Pi}+\mathrm{nPi}) / \mathrm{Nt})
$$

Where

$\mathrm{Pi}$ is the number of pioneer species;

$\mathrm{nPi}$ is the number of non-pioneer but sun-loving species and $\mathrm{Nt}$ is the total number of species in the habitat.

Table 1: Significance of the Pioneer Index values (Hawthorne, 1996) ${ }^{[14]}$

\begin{tabular}{|c|c|}
\hline Pioneer Index (IP) & Comment \\
\hline $0 \leq \mathrm{IP}<25$ & Undisturbed to minimally disturbed site / fully restored site \\
\hline $25 \leq \mathrm{IP}<50$ & Low disturbance site / good recovery \\
\hline $50 \leq \mathrm{IP}<100$ & Moderately disturbed site / average vegetation recovery \\
\hline $100 \leq \mathrm{IP}<150$ & Fairly disturbed site / weak recovery \\
\hline $150 \leq \mathrm{IP}<200$ & Very disturbed to completely transformed site/ very little recovery \\
\hline
\end{tabular}




\subsubsection{Regeneration potential}

Reconstitution is the set of dynamic processes that allow the reconstitution of a cover that has been damaged (Alexandre, 1989) ${ }^{[5]}$. It also means regeneration according to Alexandre (1989) ${ }^{[5]}$. Regeneration constitutes the potential of the forest. The presence of seedlings implies the existence of progenitors (Koulibaly, 2008) ${ }^{[22]}$. The analysis of regeneration was done on the basis of the regeneration potential (RP) by the following formula:

$P R=\frac{N j}{N} * 100$
$\mathrm{Nj}$ : total number of young plants $(\mathrm{DBH}<5 \mathrm{~cm}$ ) or total number of juvenile plants; $\mathrm{N}$ : total number of all tree individuals.

\section{Results}

\subsection{Floristic richness}

The analysis of the results shows that the secondary forest has the highest floristic richness, while the lowest floristic richness is recorded in the former annual crop (Table 2). The lowest floristic richness was recorded in the former annual crop (Table 2).

Table 2: Specific richness of the environments of the Soubré biodiversity refuge zone

\begin{tabular}{|c|c|c|c|c|c|c|c|}
\hline \multirow{2}{*}{ Floristic richnes } & \multicolumn{7}{|c|}{ Habitats } \\
\cline { 2 - 8 } & & $\begin{array}{c}\text { Ancient cocoa } \\
\text { farming }\end{array}$ & $\begin{array}{c}\text { Former rubber } \\
\text { tree cultivation }\end{array}$ & $\begin{array}{c}\text { Secondary } \\
\text { Forest }\end{array}$ & $\begin{array}{c}\text { Old mixed } \\
\text { farming }\end{array}$ & $\begin{array}{c}\text { Former } \\
\text { annual crop }\end{array}$ & Total \\
\hline Number of species & 7 & 34 & 35 & 45 & 17 & 5 & 143 \\
\hline Number of familiers & 6 & 26 & 23 & 27 & 14 & 5 & 101 \\
\hline Number of types & 7 & 33 & 33 & 39 & 17 & 5 & 134 \\
\hline
\end{tabular}

\subsection{Specific Diversity}

The values of the calculated Shannon indices show that the secondary forest has the highest value with an average of 3.807. This environment is therefore the most diverse in terms of plant species. The former cocoa, rubber and mixed crops have respective values of 3.526, 3.555 and 2.833. The bare soil (1.946) and the old annual crop (1.609) are the least diverse habitats (Table 3).

Simpson's index shows that secondary forest (0.978), former rubber cultivation (0.971), former cocoa cultivation (0.970) and former mixed cultivation (0.941) are the most diverse habitats, followed by bare soil (0.857) and former annual cultivation (0.8) (Table 3). Overall, the probability that two individuals selected from one of the habitats belong to the same species is high.

Taking all individuals into account reveals that bare soil and secondary forest of equal value have the highest Piélou equitability index (1). These habitats are followed by the former cocoa, mixed, rubber and annual crops, which have respective equitability index values of 0.99 each (Table 3 ). The species in the refuge area are evenly distributed. The refuge area is balanced.

Table 3: Species diversity indices of the different habitats of the Soubré Dam biodiversity refuge area

\begin{tabular}{|c|c|c|c|c|}
\hline Habitats & Shannon Index & Simpson Index & Piélou Index & Number of species \\
\hline Secondary forest & 3,807 & 0,978 & 1 & 45 \\
\hline Ancient cocoa farming & 3,526 & 0,971 & 0,99 & 34 \\
\hline Former annual crop & 1,609 & 0,8 & 0,99 & 5 \\
\hline Old mixed farming & 2,833 & 0,941 & 0,99 & 17 \\
\hline Former rubber tree cultivation & 3,555 & 0,971 & 0,99 & 35 \\
\hline Bare ground & 1,946 & 0,857 & 1 & 7 \\
\hline
\end{tabular}

\subsection{Floristic similarity of the different environments}

The values of Sorensen's similarity coefficient vary from 6.3 to $100 \%$. The different floristic similarities observed between the environments are found in the old annual crop and the old cocoa crop (56.4\%). Similarly, the forest and the former annual crop are floristically similar at 53.8\%. There is also a similarity between the old annual crop and the old mixed crop (55.8\%). Finally, the old mixed crop is similar to the old rubber crop with $52.5 \%$ (Table 4 ).

Table 4: Similarity index between the different habitats of the Soubré Dam biodiversity refuge area

\begin{tabular}{|c|c|c|c|c|c|}
\hline Habitats & $\begin{array}{c}\text { Secondary } \\
\text { forest }\end{array}$ & $\begin{array}{c}\text { Ancient cocoa } \\
\text { farming }\end{array}$ & $\begin{array}{c}\text { Former annual } \\
\text { crop }\end{array}$ & $\begin{array}{c}\text { Old mixed } \\
\text { farming }\end{array}$ & $\begin{array}{c}\text { Former rubber tree } \\
\text { cultivation }\end{array}$ \\
\hline ground
\end{tabular}

\subsection{Distribution of individuals by diameter class}

The histograms of the distribution of stems by diameter classes show variability between individuals. Four (4) diameter classes are represented by the histograms in each environment. For all the environments, small diameter stems ( 0 to $10 \mathrm{~cm}$ ) are the most numerous. Next come stems with diameters between 10 and $20 \mathrm{~cm}$, followed by stems with diameters between 30 and $40 \mathrm{~cm}$. On the other hand, stems with diameters greater than or equal to $50 \mathrm{~cm}$ are very poorly represented or almost absent in the habitats of former mixed farming and bare soil (Figure 3). The histograms have an "inverted J" shape. 


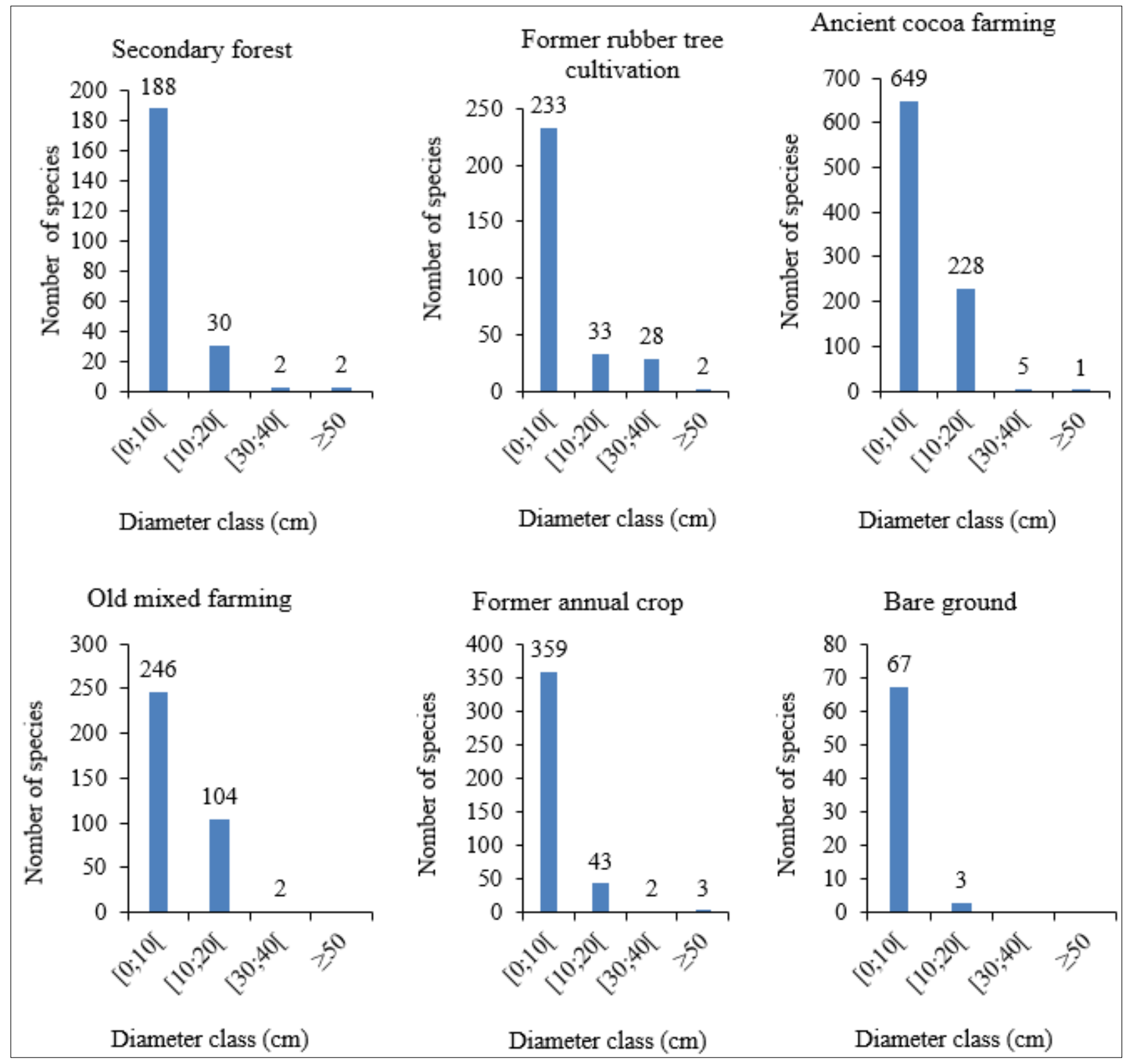

Fig 3: Stem diameter of floral species in the Soubré refuge area

3.5. Regeneration of tree species in the Soubré refuge area

\subsubsection{Modes of spread}

Four (4) modes of spread were identified in the Soubré refuge zone. These are Endozoochory, Anemochory, Barochory and Ornithology. Of these modes, Endozoochory is the most distinctive with a mean value of 824 individuals. This mode is followed by Anemochory, Barochory and Ornithology with values of 258, 146 and 8 respectively.

Of these four modes of spread in the Soubré refuge area, two are more important in the secondary forest.
Endozoochory is the most notable with an estimated value of 103 followed by Anemochory with a value of 28. At the level of ancient cultures, three modes of dissemination are distinctive. These are Endozoochory, the most distinctive (721) followed by Anemochory (227) and Barochory (145). Ornithology is the lowest mode with a value of 6 individuals. As for bare soil, only one mode is present. This is Anemochory with a value of 3 . Figure 4 presents the modes of dissemination of the species in the different environments. 


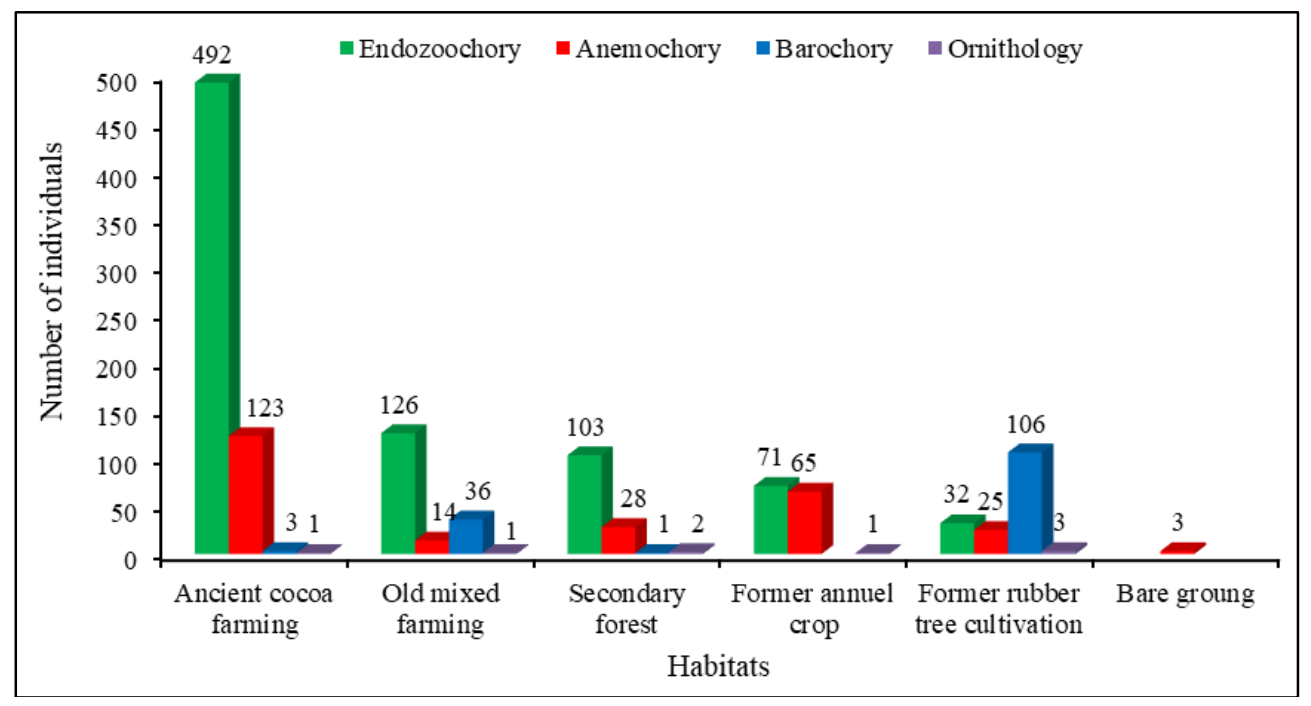

Fig 4: Patterns of spread observed in the habitats of the Soubré refuge area

\subsubsection{Pioneer Index of the different environments}

The pioneer index (PI) of the refuge zone varies from 73.49 to 158.10 . It is of the order of $158.10,140,139.63$ and 124.32 respectively for the former rubber tree crop, the bare soil, the secondary forest and the former annual crop. For the former mixed crop and cocoa, the PI is 85.79 and 73.49 . The former rubber crop has the highest PI (Figure 5).

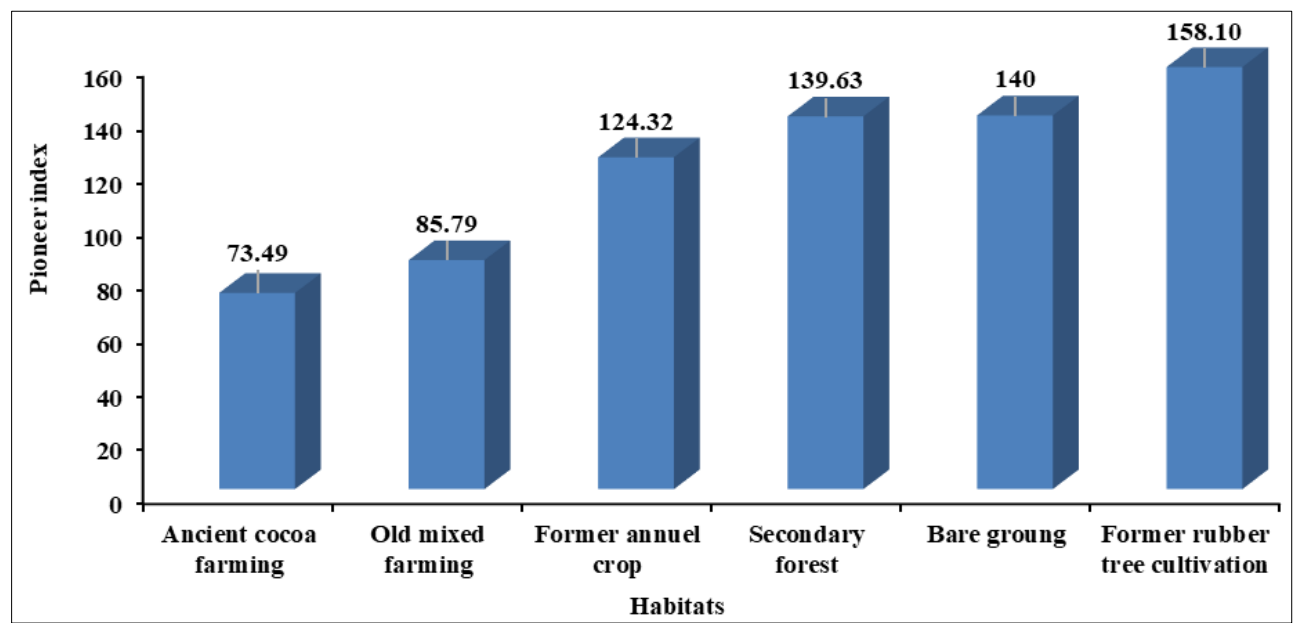

Fig 5: Pioneer indices observed in the habitats of the Soubré refuge area

\subsubsection{Regeneration potential of tree species}

Concerning the regeneration potential (RP) of the species, its value is higher in the bare soil and low in the old annual crop (0.69). In the secondary forest, the former rubber, mixed and cocoa crops, their respective values are 61.26; 60.81; 46.59 and 37.93 (Figure 6).

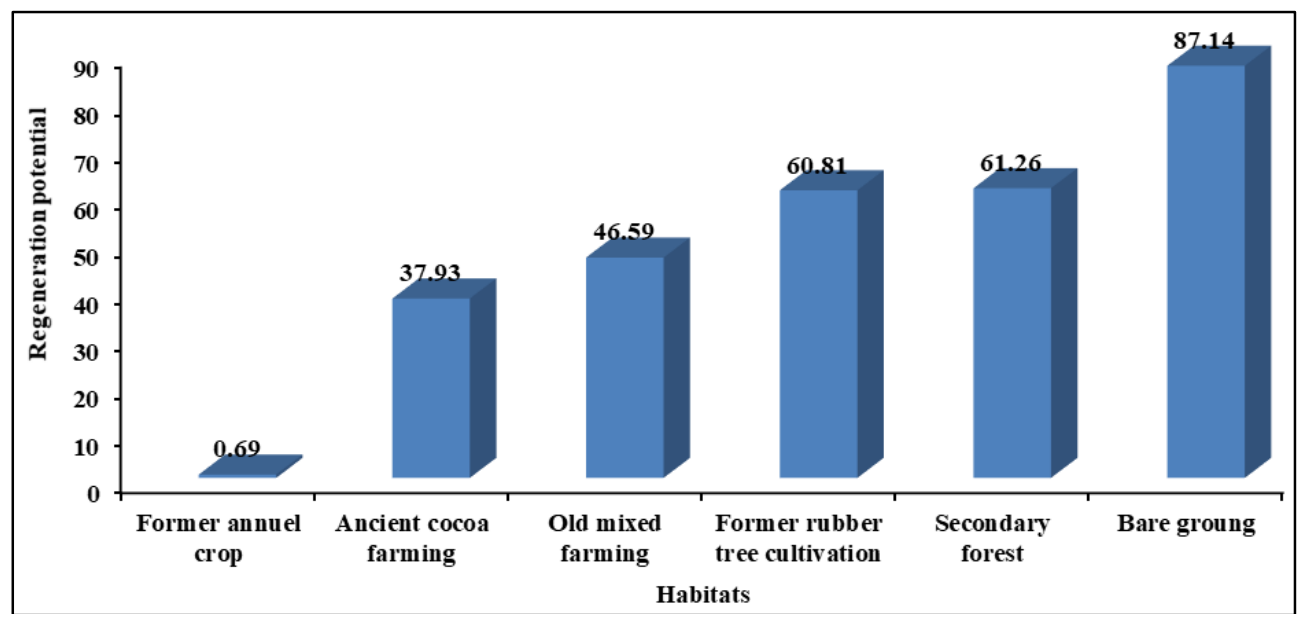

Fig 6: Regeneration potential of species in different environments 


\section{Discussion}

Our botanical inventories have enabled us to count 143 plant species in 118 genera and 53 families. As far as habitats are concerned, the secondary forest is richer in species while the former annual crop is less rich. This is due to the fact that the secondary forest has some of the characteristics of the primary forest (lianas, tree shrubs, etc.) and is well preserved compared to the old annual crop which is regularly cleared by farmers to make way for yams, cassava, vegetables, etc. Our results differ from those of Yao et al. (2020) ${ }^{[35]}$ who obtained 346 plant species divided into 262 genera and 92 families during their studies on utility plants in the Soubré biodiversity refuge zone. This represents a difference of 203 species, 144 genera and 39 families. This difference can be explained by the fact that most of their inventory took place in secondary forest, whereas ours was carried out mainly in the former cultivated areas. The families Fabaceae, Apocynaceae, Euphorbiaceae, Moraceae and Annonaceae occupy a prominent place in the Soubré biodiversity refuge. These results confirm the observations of Aké-Assi (1984) ${ }^{[4]}$ who reported that these families are the most numerous in Côte d'Ivoire. The biodiversity refuge zone owes its floristic richness to the variability of the habitats found there. Our results corroborate those of N'Guessan (2018) ${ }^{[25]}$ in his study on the classified forest of Agbo 1 in Côte d'Ivoire. According to him, the strong presence of families is justified by the coexistence of natural and anthropogenic habitats.

Overall, small diameter stems [0;10 cm] and [10;20 cm] are the most numerous. The histograms of the distribution of individuals by diameter class for the different habitats in the area show an inverted J-shape. This shape reflects the abundance of regenerating individuals (woody recruits) and individuals that have acquired regeneration (young individuals). This high proportion of woody recruits and young individuals is proof of the stability of a forest whatever its size (Rollet, 1974) ${ }^{[26]}$. Also, this form is identical in most tropical forests according to the authors Adou (2005) ${ }^{[2]}$ and Vroh (2013) ${ }^{[33]}$. This study showed that Endozoochory is the predominant mode of spread in the biodiversity hotspot followed by Anemochory and Barochory. The importance of Endozoochory is reported in most works on the forests of Côte d'Ivoire (Alexandre, 1989; Chapman, 1995; Kassi and Decocq, 2006) ${ }^{[5,9,17]}$. This spread involves, above all, birds and some frugivorous vertebrates, notably antelopes, monkeys, rats and squirrels (Kassi, 2006) ${ }^{[16]}$. The recovery and maintenance of zoochorous plant species can only be ensured if diaspores have been dispersed by animals. Seedlings from seeds transported by endozoochory are more competitive, as they avoid competition with the mother plant (Koffi, 2016) ${ }^{[20]}$. Furthermore, the importance of anemochores in the Soubré refuge area is mainly due to the abundance of crops. These formations are known for their richness in anemochorous species such as Albizia spp, Ceiba pentandra L. Gaerth, Chromolaena odorata L. King, etc. (Kassi and Decocq, 2006) ${ }^{[17]}$. Indeed, anemochory is a main dissemination strategy for plants in open environments (Bangirinama et al., 2010) ${ }^{[6]}$. The habitats of the refuge area are open spaces, which justifies the presence of these species after the endozoochories. The barochore mode is poorly represented in the different habitats of the refuge zone, as it is in the Sanaimbo classified forest (Kassi, 2006) ${ }^{[16]}$. From the results of the pioneer index (PI), we can say that the refuge zone is dominated by three trends. A first trend with a very low recovery in the former rubber cultivation, a second trend with a low recovery in the former annual cultivation, secondary forest and bare soil habitats and the last trend with an average recovery in the former cocoa and mixed cultivation. The very low recovery in the former rubber tree cultivation is due to the fact that rubber trees are a heliophilic and invasive species whose seeds inhibit the germination and proliferation of other plant species in this habitat. The low recovery in the old annual crop, secondary forest and bare soil habitats is explained by the strong presence of bats that strip the foliage from large trees in the secondary forest and the felling of large trees and also the use of pesticides in the old annual crop and bare soil habitats. Finally, the average recovery in the old cocoa and mixed crop habitats is due to the dominance of sciaphilous species in these environments. Indeed, the cocoa trees planted in a given period progressively evolve at the same time as the canopy. Thus, once the canopy is formed, the shade and dry biomass form numerous leaves and cover the ground. Our results are different from those of Koffi (2016) ${ }^{[20]}$ in Azagny National Park where the highest pioneer index was 87.3. This difference is explained by the habitats observed. His are forests including periodically flooded forest, swamp forest and old growth forest. The results of the regeneration potential (RP) calculation show that the bare soil has the highest regeneration potential with a value of 87.14 while the lowest regeneration potential is 0.69 for the old annual crop. This result obtained at the level of the bare soil, is explained by the fact that this environment being completely stripped during the construction of the dam, the pioneer species are the first to colonise this habitat. In addition, factors such as mode of spread, viability, dormancy and seed predation (Condit et al., 2000; Khurana and Singh, 2001) ${ }^{[10,19]}$ and other environmental factors such as soil structure, temperature, direction, wind speed and local topography favour a good level of regeneration of the flora (Ceccon et al., 2006; Vieira and Scariot, 2006) ${ }^{[8,32] .}$ The low regeneration potential in the former annual crop is explained by the high presence of lowland in this habitat, which is less conducive to the proliferation of sun-loving species. The results thus obtained are different from Koffi (2016) ${ }^{[20]}$. This is due to the fact that the habitats in Azagny National Park are abandoned cocoa plantations.

\section{Conclusion}

This study conducted in the Soubré refuge area showed that the flora is rich in 143 species divided into 118 genera and 53 families. The secondary forest is the richest habitat with 45 species. The high dominance of Guinean-Congolese (GC) species is evidence that the refuge area belongs to a forest zone. With respect to the distribution of diameter classes, our results reveal that the refuge zone is in recovery. This is explained by the inverted J-shape of the histograms. In view of the pioneer index, we can say that the reconstitution is very weak at the level of the former rubber plantation.

After assessing the floristic diversity of the refuge area, it should be noted that this area contains a significant number of species. For these reasons, it would be necessary to increase the monitoring of the biodiversity refuge area by creating physical barriers within the boundaries to allow for better ecological compensation of this area. 


\section{References}

1. Abrou NEJ. Mission de suivie de la zone de conservation de la biodiversité, Mission, 2019, 19.

2. Adou Yao CY, Bakayoko A, Akpatou KB, N’Guessan KE. Impacts de pressions anthropiques sur la flore et la structure de la végétation dans la forêt classée de Monogaga, Côte d'Ivoire. Journal of Animal \& Plant Sciences 2011;12:1560-1572.

3. Adou Yao CY. Pratiques paysanne et dynamique de la biodiversité dans la Forêt Classée de Monogaga (Côte d'Ivoire). Thèse de doctorat, Département Hommes Natures Sociétés, Muséum National d'Histoire Naturelle, Paris, 2005, 233.

4. Aké-Assi L. Flore de la Côte d’Ivoire: étude descriptive et biogéographique avec quelques notes ethnobotaniques. Thèse d'Etat Université faculté des Sciences, (Côte d'Ivoire, Abidjan) Tome III: 1984, 1069-1206.

5. Alexandre DY. Dynamique de la régénération naturelle en forêt dense de la Côte d'Ivoire. Office de la recherche scientifique et technique outre-mer, Paris (France), 1989, 102.

6. Bangirinama F, Bigendako MJ, Lejoly J, Noret N, De Cannière $\mathrm{C}$, Bogaert J. Les indicateurs de la dynamique post-culturale de la végétation des jachères dans la partie savane de la réserve naturelle forestière de Kigwena (Burundi). Plant Ecology and Evolution, 2010;143:138-147.

7. Bouzillé JB. Gestion des habitats naturels et biodiversités: concepts, méthodes et démarches. Lavoisier, Paris, France, 2007, 330.

8. Ceccon E, Huante P, Rincon E. Abiotic Factors Influencing Tropical Dry Forests Regeneration. Brazilian Archives of Biology and Technology 2006;49:305-12.

9. Chapman CA. Primate seed dispersal: coevolution and conservation implication. Evolutionary Anthropology, 1995;4:74-82.

10. Condit R, Ashton PS, Baker P. Spatial Patterns in the Distribution of Tropical Tree Species. Science 2000;288:1414-1418.

11. Forest resources assement. Rapport national Bénin, 2010, 54.

12. Hakizimana P. Analyse de la composition, de la structure spatiale et des ressources végétales naturelles prélevées dans la forêt dense de Kigwena et dans la forêt claire de Rumonge au Burundi. Thèse de Doctorat, Université Libre de Bruxelles, Belgique 2012, 141.

13. Hassane DC. Intégration de la biodiversité dans l'évaluation environnementale stratégique des aménagements dans le bassin fluvial du programme Kandadji au Niger. Thèse de Doctorat en Science de l'Environnement, Université du Québec, Montréal, 2013, 352.

14. Hawthorne WD. Holes and the sums of parts in Ghanaian forest: regeneration, scale and sustainable use. Proceedings of the Royal Society Edinburgh, 1996;104:75-176.

15. Jeune Volontaire pour l'Environnement (JVE). Rapport d'evaluation des impacts sociaux et environnementaux du barrage de Soubré Côte d'Ivoire 2017, 31.

16. Kassi NJ. Successions secondaires post-culturales en forêt dense semi-décidue de Sanaimbo (Côte d'Ivoire): nature, structure et organisation fonctionnelle de la végétation. Thèse Doctorat, Université de Picardie Jules Verne, France, 2006, 232.

17. Kassi NJ, Decocq G. Régénération de la forêt dense semi-décidue dans les stades postculturaux en forêt classée de Sanaimbo (Côte d'Ivoire). Journal of Vegetation Science 2006;92:395-405.

18. Kassoum T. Le couvert forestier en Côte d'Ivoire: une analyse critique de la situation de gestion des forêts (classées, parcs et réserves). The International Journal of Social Sciences and Humanities Invention, 2018;5(2):4387-4397.

19. Khurana E, Singh JS. Ecology of tree seed and seedlings: Implications for tropical forest conservation and restoration. Current Science 2001;80:748-57.

20. Koffi KAD. Dynamique de la végétation et valeurs de conservation des espaces anciennement cultivés du parc national d'Azagny (sud de la Côte d'Ivoire). Thèse de Doctorat, UFR Biosciences, Université de CocodyAbidjan, Côte d’Ivoire 2016, 213.

21. Koné M, Kouadio YL, Neuba DF, Malan DF, Coulibaly L. Evolution de la couverture forestière de la Côte d’Ivoire des années 1960 au début du 21 ème siècle. International Martinurnal of Innovation and Applied Studies 2014;7(2):782-794.

22. Koulibaly AV. Caractéristique de la végétation et dynamique de la régénération, sous l'influence de l'utilisation des terres, dans des mosaïques forêtssavanes, des Régions de la Réserve de Lamto et du Parc National de la Comoé, en Côte d'Ivoire. Thèse de Doctorat, UFR Biosciences, Université de CocodyAbidjan, Côte d’Ivoire 2008, 137.

23. Martin P. Influence de la fragmentation forestière sur la régénération des espèces arborées dans le Sud-Ouest de la Côte d'Ivoire. Thèse de Doctorat: Université de Genève, Suisse 2008, 320.

24. Missa K, Seguena F, Soro D, Piba S-C, Bakayoko A. État actuel de la relique forestière de l'Université Nangui Abrogoua, Côte d'Ivoire: impacte des pressions anthropiques sur sa flore et sa structure de la végétation. Afrique SCIENCE 2018;14(5):229-238.

25. N’Guessan AE. Dynamique de la végétation et facteurs de reconstitution de la biomasse des forêts secondaires dans la forêt classée d'Agbo 1 (Côte d'Ivoire). Thèse de Doctorat Université Félix Houphouët Boigny 2018,179.

26. Rollet B. L'architecture des forêts denses humides sempervirentes de plaines. Paris, Centre Technique Forestier Tropical 1974, 298.

27. Sangne YC. Dynamique du couvert forestier d'une aire protégée soumise aux pressions anthropiques: cas de la Forêt Classée de Téné (département d’Oumé, CentreOuest de la Côte d'Ivoire). Thèse de doctorat, Université de Cocody Abidjan 2009, 167.

28. Sheil D, Van Heist M. Ecology for tropical forest management. International Forestry Review 2000;2:261-270.

29. Simpson EH. Measurement of diversity. Nature 1949;163:160-163.

30. Sinsin B, Kampmann D. Atlas de la biodiversité de l'Afrique de l'Ouest. Bénin Cotonou et frankfurt / Main. BIOTA, Tome 2010;I:676.

31. Sorensen T. A method of establishing groups of amplitude in sociology based onsimilarity of content, 
and its application to analysis of the vegetation on Danish commons. Biologisfter 1948;5:1-34.

32. Vieira DLM, Scariot A. Principles of Natural Regeneration of Tropical Dry Forests for Restoration. Restoration ecology 2006;14(1):11-20.

33. Vroh BTA. Évaluation de la dynamique de la végétation dans les zones agricoles d'Azaguié (Sud-Est, Côte d'Ivoire). Thèse Doctorat, UFR Biosciences, Université Cocody- Abidjan, Côte d’Ivoire 2013, 208.

34. Vroh BTA, Kouamé NF, Tondoh EJ. Étude du potentiel de restauration de la diversité floristique des agrosystèmes de bananiers dans la zone de Dabou (Sud Côte d'Ivoire). The Science of Nature 2011;8(1):37-52.

35. Yao KJC, Kpangui KB, N’Guessan YO, Tiébré MS, Ouattara D, N'Guessan KE. Disponibilité des plantes utilitaires dans la zone de conservation de biodiversité du barrage hydroélectrique de Soubré, Sud-Ouest, Côte d’Ivoire. Afrique Science 2020;16(6):65-74. 